\title{
Financial Performance and On-Line Reputation: Empirical Evidence from a Random Sample of European Food Industry
}

\author{
Assoc. Prof. Radovan Bačík, PhD. MBA \\ University of Prešov, Slovakia, radovan.bacik@unipo.sk
}

MSc. Francesco Paolone, PhD

University of Teramo, Italy, fra.paolone@gmail.com

Ing. L'udovit Nastišin

University of Prešov, Slovakia, Iudovit.nastisin@gmail.com

\section{Doi:10.5901/mjss.2016.v7n1p105}

\begin{abstract}
In this paper we examine the relationship between the financial performance ratios and the online reputation among 60 European enterprises belonging to the "Food industry. After setting a quantitative statistical analysis. this is what emerged: customers are not influenced by financial performance ratios since the statistics are not significant. This confirmed our hypothesis that financial performance and online reputation are two independent and not linked research fields. In conclusion, as we expected, online reputation depends upon values and emotions transmitted by the power as well as the brand.
\end{abstract}

Keywords: Online reputation, Performance Measurement, Financial Accounting, Food Industry.

\section{Introduction}

The purpose of this study is to determine whether there exists a relation of dependency between online reputation and the financial performance ratios through the analysis of a random sample of 60 European public limited companies belonging to the Food Industry. The results show that Performance Measurement Ratios and Online Reputation are independent each others.

Our study contributes to the literature in the following way. The Online Reputation has become increasingly important over the past year, either for large and small and medium size enterprises. Our analysis presents an approach to the study of the relationship between Online Reputation and Financial Performance. Overall objective of this article is to enlighten the emerging phenomenon of on-line reputation of an entity and present it as the important factor which is helpful for estimation of performance of the company. Also it tries to make clear that both areas researched are independent thus both need necessary attention to manage so they can support the performance.

In the second section we discuss the theoretical background through the literature and by going into details of the definition of Online Reputation. The third section provides the research methodology and Data analysis. In the fourth section we present the empirical results. The fifth section provides conclusions and comments on the paper. Several suggestions for further research are also presented.

The hypothesis addressed in this study is: $\mathrm{H}_{0} \rightarrow$ Overall, there is no linear relationship between financial performance ratios and online reputation through the analysis of a random sample of public limited companies belonging to the European food industry.

\section{Theoretical Background}

\subsection{Defining Reputation}

Reputation is a concept commonly used in Internet marketing and it generally means an overall presence on the Internet. We can compare it to leaving footprints. All activities are interconnected and complement one another (Janouch. 2011. p. 17). Each company has a reputation or online reputation, whether they want it or not; the reputation does exist (Marsden 2013; Gavurová, 2011). If you are running your own business, you should not leave your reputation to chance. It is your 
ultimate responsibility. Company's reputation is considered to be very valuable asset (Šoltés and Gavurová, 2013). As George Washington once said: "With a reputation you can do anything, without one nothing" (Haywood 2002. p. 9). However, if we consider corporate reputation, its definition is a bit complicated (Griffin 2008). Balmer and Greyser (2003) characterize corporate reputation as being created over time, based on what the organization did and how it behaved. According to Bromley (2002), company or corporate reputation only reflects relative standing of the company, both internally with its employees and externally with other stakeholders, in its competitive as well as its institutional environments. Highhouse defines corporate reputation as a global, stable over time, evaluative judgement about a company that is shared by multiple constituencies (In: Helm et al. 2011). It is a pure reaction of customers, investors, employees and other stakeholders. It is a collective judgement of individual impressions (Gottschalk 2011).

\subsection{Trust in the context of reputation of an entity}

Trust fulfils every company in a million of different ways. No institution can function without it. Trust is a strong belief that we can rely on someone (Shore, 2005; Šoltés and Gavurová, 2015). Shaw offers alternative definition (In: Armstrong 2007); he defines the concept of trust as a belief that those on whom we depend will meet our expectations of them. These expectations depend on our critical judgment of other person's responsibility to meet our needs. Tavakolifard and Almeroth (2012) claim that generally accepted definition of trust is still missing despite comprehensive studies of philosophers, sociologists and psychologists. It is easier to identify individual features of trust than to determine exactly what it means. Uddin, Zulkernine and Ahamed (2008) argue that trust (or symmetrically, distrust) is a particular level of the subjective probability with which an agent assesses that another agent or group of agents will perform a particular action, both before he can monitor such action (or independently of his capacity ever to be able to monitor it) and in a context in which it affects his own action. An agent is generally an individual or a thing (entity) which affects the environment or other agents and has features and its own targets which it strives to achieve. The conceptuality of trust means that the trust of entity "A" towards entity "B" is always dependent on certain context "C".

We'd like to point out the work of Jøsang et al. (2005) who deals with "the issue of trust" (in terms of creating trust establishing credibility and making decisions on the basis of credibility). Jøsang et al. (2006) states that it is an oriented relationship consisting of two pieces. Those are the subject and the object of the trust. The term oriented is used in the sense of clear distinction of resources (subject) and goals (object) of the relationship. The authors further define two categories: Context-independent (reliability trust) and Context-dependent (decision-trust). (Jøsang et al. 2005; Szczygiel et al. 2015)

\subsection{Classification of models based on trust and reputation}

Jordi Sabater and Carles Sierra (2003) in their work Review on Computational Trust and Reputation Models have specified classifications which focus on major models and try to find common features based on which individual classification methods and their categories are designed. Basic classification criterion is the so called model type. Model type means whether the model works with trust or reputation.

- models of trust - work only with trust.

- models of reputation - work only with reputation.

- hybrid models - work both with trust and reputation.

According to these authors, models can be classified on the basis of determining the origin of information (knowledge) which is used for the evaluation of reputation, as well as confidence. These include (Sabater. Sierra. 2003, Michalski 2014): direct experience, hearsay information, sociological knowledge and prejudice.

\subsection{From the image to the reputation}

Companies have invested large amounts of financial resources and hired agencies and marketing professionals to prepare communication campaigns to support such brand image that would create an incentive for the customers to make purchases (Leboff 2011). This argument is supported by Smaiziene and Jucevicius (2009) who claim that companies prefer to focus primarily on the image and leave the reputation behind. Grant Leboff (2011) mentions that the image is not a guarantee of positive comments and recommendations. These will only be achieved due to good reputation. In other words, the foundation of modern marketing is not the image which the company strives to create, but the reputation which it has actually established (Pollák, 2013).

As regards the image and reputation, Bennet and Kottasz point out time dimension (time of creation) as the main 
characteristics which distinguish these two constructs. In other words, company's image can be created in a short time. Reputation is generated in a longer time frame and therefore cannot be changed or redirected as quickly as the image (In: Smaiziene.Jucevicius 2009). Such an approach is also supported by Jackson (2004) and Cornelissen (2004) who argue that the time of establishment or creation is one of the main differences between the image (short time of creation) and reputation (long time of creation). Fill (2009) perceives reputation as wider set of images. He is also of the opinion that reputation change is more time consuming and difficult while image can be influenced much faster. Therefore, it may be said that reputation and image are not synonymous, as some authors point out, yet they are closely related and interdependent elements (Pollák, Dorčák, Szabo, 2014).

\subsection{Creation of reputation}

According to Svoboda (2009), reputation of any organization is composed of three forms. i.e. primary, secondary and cyclic. Harris Fombrun defined reputation as collective assessment of the company's ability to provide valuable product, service or other value to a group of customers. They have developed a scale that measures corporate reputation, which they call corporate reputation quotient (RQ). $\mathrm{RQ}$ is a complex method of measuring corporate reputation (In: Walsh. Beatty 2007).

Corporate reputation building has been primarily attributed to the area of marketing and communication. Burke et al. (2011) state that nowadays the corporate reputation has been integrated into human resource management and corporate strategy. Reputation is communicated to the public by the organisation's managers. It is generally accepted that reputation begins from the inside out. Fombrun and Foss (2011) noted that it is good if the organization takes care of its reputation, and they emphasized the following factors:

1. The Principle of Distinctiveness - Strong reputation arises when companies own a distinctive position in the minds of customers.

2. The Principle of Focus - Strong reputation arises when companies focus their actions and communication around a single core theme.

3. The Principle of Consistency - Strong reputation arises when companies are consistent in their actions and communication with internal as well as external environment.

4. The Principle of Identity - Strong reputation arises when companies act in ways that are consistent with espoused principles of identity. The main task is that the companies are perceived as real by its customers and the public.

5. The Principle of Transparency - Strong reputation arises when companies are transparent in the way they conduct their affairs. In particular, companies should be perceived as open and honest in their business activities. Transparency requires communication - a lot of it.

\subsection{Reputation in online environment}

Walter (2013) argues that reputation in life and business is everything. It means that reputation is very fragile and one mistake may sometimes cause irreversible damage. This is especially true in the digital world where radical transparency and demanding customers have the greatest power. According to Chernatony et al., if the Internet offers consumers a new way to share information about companies and brands, then it also allows the companies to control information about them. Consumers are able to obtain information on potential suppliers and products, but they can also create new content on the Internet which may affect the perception of other consumers and stakeholders of the respective company. Negative comments on the Internet can quickly and seriously damage the image and reputation of the brand (In: Siano et al. 2011), eWOM (electronic word of mouth) is an important part of online reputation. According to Henning-Thurau (2004), this form of communication may be defined as any positive or negative statement made by potential, actual or former customers about a product or company via the Internet.

Jun Loayza (2013) presents basic principles of online reputation management which he divides into various segments such as Quick Fix. Long-Lasting, Content Driven and Relationship Driven.

\section{Research Methodology and Data Analysis}

The analysis was conducted on the Top 20 Public Limited Companies and other 40 picked randomly from the list of all public limited companies belonging to the Food Industry in Europe. We selected the public limited companies with more than 500 employees in the last available fiscal year (2013). These companies were ranked by Sales Revenues. The 
following is the sampling process which shows the selection criterion.

Table 1 - Selection Criterion 1

\begin{tabular}{|l|l|}
\hline Country & All European Countries \\
\hline Legal Form & Public Limited Companies \\
\hline Industry Sector & NACE Rev.2: 10 - Manufacture of Food Products \\
\hline Selection Criteria & Number of Employees min=500 in year 2013 \\
\hline
\end{tabular}

Source: own elaboration

Table 2 - Selection Criterion 2

\begin{tabular}{|l|l|l|}
\hline Picked the first 20 companies & Picked 20 companies randomly & Picked 20 cmpanies randomly \\
\hline Sales Revenues $>1.000 .000 €$ & $1.000 .000 €<$ Sales Revenues $<200.000 €$ & Sales Revenues $200.000 €$ \\
\hline
\end{tabular}

Source: own elaboration

According to the previous table, 60 companies were selected from three brackets: 20 of them achieved Sales Revenues higher than $€ 1.000$ million, other 20 companies between $€ 200$ million and $€ 1,000$ million and the last 20 less than $€ 200$ million.

A coding sheet was used for data collection. The coding sheet was developed in Excel spreadsheet and included the name of the company, the country and the 6 financial performance ratios: ROAE, ROE, Current Ratio, Quick Ratio, Debt To Equity Ratio and Funded Capital Ratio.

Measuring the performance of a company and its effectiveness has been a frequently discussed area over many years. One of those discussions states that it can be defined as the quantification consisting of measurement action. This connection of quantification and action shows the performance (Healy et al. 1995; Michalski 2010). In this paper, we will consider six main effectiveness-related dimensions of performance according to Bragg (2007), which better describe the economic and financial conditions. These ratios are:

ROAE (Return on Asset Employed): A company needs to keep investors from having to put more cash into the company. Consequently, the return on assets employed measure is critical in assessing the level of returns from short and long-term investments (Bragg, 2007). It can be obtained as:

\section{$\frac{\text { Net Income }}{\text { Total Assets }}$}

ROE (Return on Equity): It is used by investors to determine the amount of return they are receiving from their capital investment (Shareholders' funds) in an organization. This measure allows for the better draw of the company's ability to generate revenues from its activities (Bragg, 2007). Here is the formula:

\section{$\frac{\text { Net Income }}{\text { Total Equity }}$}

Current Ratio: The current ratio is used by lenders to determine whether a company has a sufficient level of liquidity to pay its liabilities (Bragg, 2007). The formula is:

$\frac{\text { Current Assets }}{\text { Current Liabilities }}$

Quick Ratio: Current Ratio is usually not the best measure of liquidity because of the presence of inventory. A better understanding of a company's very short-term ability to generate cash is the Quick Ratio which excludes inventory from the current assets portion of the current ratio (Bragg, 2007).

Cash $_{t}+$ Market securities $_{t}+$ Accounts receivable $_{t}$

\section{Current Liabilities,}

Debt to Equity Ratio: It reveals the extent to which s company's management is willing to fund its operations with debt rather than own funds (Bragg, 2007).

$\frac{\text { Debt }_{t}}{\text { Equity }}$

Funded Capital Ratio: This ratio indicates the amount of fixed assets that are being funded by long-term funding (shareholders' funds and long term debts) (Bragg, 2007). The formula is: 


\section{(Shareholders' Equity $y_{t}+$ Long-term Debts $)$ \\ Fixed Assets $s_{t}$}

In doing so, we examine the relationship between the above mentioned indicators (explanatory variables) and the Online Reputation in order to see if people generally based their choices on financial information in Food Industry.

One of the most commonly used systems for the evaluation of online reputation in Europe is sentiment analysis. This area was previously investigated by Rajzák et al. in order to evaluate online reputation of banks (2010). It records ratings of top 10 results in Google search. After counting sentiment points we achieve a resulting value which is a starting point for the evaluation of the success or failure of a company in a particular segment. In order to minimize the presence of personalized search results via location, search history or cookies, a proxy server has been used to eliminate these personal factors. As we aimed to minimize the factor of subjective representation of the results, the score was prepared independently by three people, and the resulting table is based on average ratings. Search phrase used was in all cases established name of these food companies.

The score obtained by the ski resorts on individual positions was subsequently counted and the final result, i.e. the total points obtained indicates the strength of sentiment of all ten results in the search engine google.sk for the specific resort. The final score thus represents the final factor for the evaluation of the success or failure.

Table 3 - Online reputation evaluation score board

\begin{tabular}{|c|c|c|c|c|c|c|c|c|c|c|}
\hline Sentiment/ Position of the result & $\mathbf{1}$ & $\mathbf{2}$ & $\mathbf{3}$ & $\mathbf{4}$ & $\mathbf{5}$ & $\mathbf{6}$ & $\mathbf{7}$ & $\mathbf{8}$ & $\mathbf{9}$ & $\mathbf{1 0}$ \\
\hline+ & 20 & 19 & 18 & 17 & 16 & 15 & 14 & 13 & 12 & 11 \\
\hline $\mathrm{X}$ & 10 & 9 & 8 & 7 & 6 & 5 & 4 & 3 & 2 & 1 \\
\hline \pm & 2 & 2 & 2 & 2 & 2 & 2 & 2 & 2 & 2 & 2 \\
\hline- & -20 & -19 & -18 & -17 & -16 & -15 & -14 & -13 & -12 & -11 \\
\hline
\end{tabular}

Source: Rajzák, 2010

\section{General Results}

The general findings were compared and reported in the below tables. Appendix B shows a detailed Online Reputation Score and Appendix $\mathrm{C}$ indicates the six financial performance ratios. The following are the general statistics on correlation between performance indicators and Online reputation.

Table 4 - Descriptive statistics

Descriptive Statistics

\begin{tabular}{|c|c|c|c|c|c|}
\hline & Nobs & Min & Max & Mean & St. Dev \\
\hline ONLINE_REP & 60 & 18.00 & 61.00 & 40.9333 & 9.85637 \\
ROA & 60 & .00 & .25 & .0676 & .05041 \\
ROE & 60 & .00 & 2.34 & .1529 & .29912 \\
CR & 60 & .44 & 3.19 & 1.3749 & .57542 \\
QR & 60 & .29 & 2.38 & .9431 & .42632 \\
D_E & 60 & -15.30 & 20.54 & 1.8688 & 3.72939 \\
F_C & 60 & -32.84 & 3.18 & .5807 & 4.41169 \\
Valid (listwise) & 60 & & & & \\
\hline
\end{tabular}

Source: own elaboration

Table 5 - Correlation matrix

\begin{tabular}{|c|c|c|c|c|c|c|c|c|}
\hline \multicolumn{9}{|c|}{ Correlation Matrix } \\
\hline & & ONLINE_REP & $\mathrm{ROA}$ & ROE & $\mathrm{CR}$ & QR & D_E & F_C \\
\hline \multirow[t]{3}{*}{ ONLINE_REP } & Pearson'sCorrelation & 1 & .031 & .002 & -.060 & .086 & .124 & -.002 \\
\hline & Sig. $(2 \text {-code })^{1}$ & & .816 & .987 & .648 & .513 & .346 & .989 \\
\hline & $\mathrm{N}$ & 60 & 60 & 60 & 60 & 60 & 60 & 60 \\
\hline
\end{tabular}

${ }^{1}$ Sig. (2-code) show an absence of significance in all the correlations since values are above 0.05 . 


\begin{tabular}{|c|c|c|c|c|c|c|c|c|}
\hline $\mathrm{ROA}$ & $\begin{array}{l}\text { Pearson'sCorrelation } \\
\text { Sig. (2-code) } \\
\mathrm{N}\end{array}$ & $\begin{array}{l}.031 \\
.816 \\
60\end{array}$ & $\begin{array}{l}1 \\
60\end{array}$ & $\begin{array}{l}.106 \\
.419 \\
60 \\
\end{array}$ & $\begin{array}{c}.486^{*+} \\
.000 \\
60\end{array}$ & $\begin{array}{c}.416^{*+} \\
.001 \\
60\end{array}$ & $\begin{array}{c}-.094 \\
.474 \\
60\end{array}$ & $\begin{array}{l}.232 \\
.075 \\
60\end{array}$ \\
\hline ROE & $\begin{array}{l}\text { Pearson'sCorrelation } \\
\text { Sig. (2-code) } \\
\text { N }\end{array}$ & $\begin{array}{l}.002 \\
.987 \\
60 \\
\end{array}$ & $\begin{array}{l}.106 \\
.419 \\
60 \\
\end{array}$ & $\begin{array}{l}1 \\
60 \\
\end{array}$ & $\begin{array}{c}-.112 \\
.392 \\
60 \\
\end{array}$ & $\begin{array}{c}-.135 \\
.302 \\
60 \\
\end{array}$ & $\begin{array}{c}.629^{*+} \\
.000 \\
60 \\
\end{array}$ & $\begin{array}{c}-.093 \\
.482 \\
60 \\
\end{array}$ \\
\hline $\mathrm{CR}$ & $\begin{array}{l}\text { Pearson'sCorrelation } \\
\text { Sig. (2-code) } \\
\text { N }\end{array}$ & $\begin{array}{c}-.060 \\
.648 \\
60 \\
\end{array}$ & $\begin{array}{c}.486^{*+} \\
.000 \\
60 \\
\end{array}$ & $\begin{array}{c}-.112 \\
.392 \\
60 \\
\end{array}$ & $\begin{array}{l}1 \\
60 \\
\end{array}$ & $\begin{array}{l}.862^{*+} \\
.000 \\
60 \\
\end{array}$ & $\begin{array}{c}-.106 \\
.420 \\
60 \\
\end{array}$ & $\begin{array}{c}.222 \\
.089 \\
60 \\
\end{array}$ \\
\hline QR & $\begin{array}{l}\text { Pearson'sCorrelation } \\
\text { Sig. (2-code) } \\
\text { N }\end{array}$ & $\begin{array}{l}-.086 \\
.513 \\
60 \\
\end{array}$ & $\begin{array}{c}.416^{*+} \\
.001 \\
60 \\
\end{array}$ & $\begin{array}{c}-.135 \\
.302 \\
60 \\
\end{array}$ & $\begin{array}{c}.862^{*+} \\
.000 \\
60 \\
\end{array}$ & $\begin{array}{l}1 \\
60 \\
\end{array}$ & $\begin{array}{c}-.073 \\
.577 \\
60 \\
\end{array}$ & $\begin{array}{c}.171 \\
.191 \\
60 \\
\end{array}$ \\
\hline D_E & $\begin{array}{l}\text { Pearson'sCorrelation } \\
\text { Sig. (2-code) } \\
\text { N }\end{array}$ & $\begin{array}{l}.124 \\
.346 \\
60\end{array}$ & $\begin{array}{c}-.094 \\
.474 \\
60 \\
\end{array}$ & $\begin{array}{c}-.629^{\text {th }} \\
.000 \\
60\end{array}$ & $\begin{array}{c}-.106 \\
.420 \\
60\end{array}$ & $\begin{array}{c}-.073 \\
.577 \\
60\end{array}$ & $\begin{array}{l}1 \\
60 \\
\end{array}$ & $\begin{array}{l}.097 \\
.461 \\
60\end{array}$ \\
\hline F_C & $\begin{array}{l}\text { Pearson'sCorrelation } \\
\text { Sig. (2-code) } \\
\mathrm{N}\end{array}$ & $\begin{array}{c}-.002 \\
.989 \\
60\end{array}$ & $\begin{array}{l}.232 \\
.075 \\
60 \\
\end{array}$ & $\begin{array}{c}-.093 \\
.482 \\
60\end{array}$ & $\begin{array}{c}.222 \\
.089 \\
60 \\
\end{array}$ & $\begin{array}{l}.171 \\
.191 \\
60 \\
\end{array}$ & $\begin{array}{l}.097 \\
.461 \\
60\end{array}$ & 60 \\
\hline
\end{tabular}

Source: own elaboration

As we can see from the previous tables, the Correlation Matrix supports/confirms our hypothesis in the way that there is no correlation between the online reputation and the performance ratios. The Pearson's Correlation values indicate that each of the performance ratio has no kind of relation with the online reputation. In doing so, we may point out that financial performance and online reputation represent two independent areas².

\section{Concluding Remarks and Suggestion for Further Researches}

Our results seek to investigate whether there exist a relationship between financial performance and online reputation among a random sample of 60 European public limited companies operating in Food Industry. According to the below analysis, we found that main financial performance ratios (ROA, ROE, Current Ratio, Quick Ratio, Debt to Equity Ratio and Funded Capital Ratio) and online reputation are two separate independent areas which don't interact between each other. The conclusion that can be drawn after analyzing financial data is that, with no doubt, the opinion of a customer is in no way influenced by the financial performance. This demonstrates that individuals are influenced by other factors like the quality of the brand. All this is explained by the correlations performed between the variables of performance ratios and online reputation that shows an absence of statistical significance as well as a dependency relationship. In conclusion, product's reputation is made primarily on the basis of values and emotions transmitted by the brand.

A promising way for such research would be assessing other industry sectors to see whether this analysis leads to different results. It would be useful to focus on a multiple countries setting (EU-nations as well as non EU countries) in order to deeply analyze the online reputation and compare findings afterwards.

Furthermore, it would also be useful to consider other performance indicators in addition to six analyzed above as well as exploring different set of indicators from different perspectives such as customers, supply chain operations, employees, corporate social responsibility etc. in order to assess whether there exists a relation of dependency. There is room for further empirical research along the lines of the Online Reputation discussed and analyzed above. However, we think it would be helpful if we could somehow find a way to consider additional performance indicators which could be connected to online reputation.

In addition to continued empirical research based on accounting data we also need better integration between different types of research. In addition to accounting data, we need to encourage high quality surveys, more wide ranging interview studies, and a more thorough development of the theoretical foundations of accounting choices.

${ }^{2}$ This findings were confirmed by the graphs in appendix that don't show a linear correlation between variables (Appendix D - Dispersion graphs). 


\section{Acknowledgement}

This article is one of the partial outputs of the current research grant VEGA no. 1/0145/14 entitled "Online Reputation Management (ORM) as a Tool to Increase Competitiveness of Slovak SMEs and its Utilization in Conditions of Central European Virtual Market".

\section{References}

Armstrong, M. (2007), A Handbook of Employee Reward Management and Practice. 10. ed. Prague: Grada Publishing, ISBN 978-80247-1407-3.

Balmer, J.; Greyser, S. (2003), Revealing the Corporation: Perspectives on Identity, Image, Reputation, Corporate Branding and Corporate-level Marketing, Oxford: Routledge, ISBN: 978-0-4152-8421-9.

Brag, S. M. (2007), Throughput Accounting: A Guide to Constraint Management, Wiley, ISBN: 978-0471251095.

Burke, J. et al. (2011), Corporate Reputation: Managing Opportunities and Threats, UK: Gower Publishing Ltd., ISBN: 978-0-566-092053.

Fill, C. (2009), Marketing Communications: Interactivity, Communities and Content. 5th Edition, UK: Pearson Education Ltd. ISBN: 9780-273-71722-5.

Fombrun, C. J.; Foss, C. B. (2001), The Reputation Quotient, Part 1: Developing a Reputation Quotient. [on-line]. [cit. 2015-05-10]. Available at: http://www.reputationinstitute.com/frames/press/01_15_14_GUAGE.pdf.

Gavurová, B. 2011. Systém Balanced Scorecard v podnikovom riadení. In: Ekonomický časopis. Vol. 59, No. 2 (2011), p. 163-177. ISSN 0013-3035

Gottschalk, P. (2011). Corporate Social Responsibility, Fovernance and Corporate Reputation. USA: World Scientific Publishing Co. Pte. Ltd. ISBN: 978-981-4335-17-1.

Griffin, A. (2008), New Strategies for Reputation Management: Gaining Control of Issues, Crises \& Corporate Social Responsibility, London: Kogan Page Publishers, ISBN: 978-0-7494-5007-6.

Haywood, R. (2002). Manage Your Reputation: How to Plan Public Relations to Build \& Protect the Organization's Most Powerful Asset, London: Kogan Page Publishers, ISBN: 978-0-7494-3794-4.

Helm, S. et al. (2011), Reputation Management, Berlin: Springer-Verlag, ISBN: 978-3-642-19265-4.

Henning-Thueau, T. et al. (2004), Electronic Word-of-mouth Via Consumer-opinion Platforms: What Motivates Consumers to Articulate Themselves on the Internet? [on-line]. [cit. 2015-05-10]. Available at: http://www.gremler.net/personal//research/2004_ Electronic_WOM_JIM.pdf.

Jackson, K. T. (2004), Building Reputational Capital: Strategies for Integrity and Fair Play that Improve the Bottom Line, USA: Oxford University Press, ISBN: 978-0-1951-6138-0.

Janouch, V. (2011), 333 Advices for internet marketing, Computer Press. ISBN 978-8025134023.

Jøsang, A. et al. (2006), Survey of Trust and Reputation Systems for On-line Service Provision, [on-line]. [cit. 2015-05-12]. Available at: http://eprints.qut.edu.au/7280/1/7280.pdf.

Leboff, G. (2011), Sticky marketing, Prague: Management Press, ISBN: 978-80-7261-235-2.

Loayza, J. (2013), The Beginner's Guide to Reputation Management: 8 Core Principles of Reputation Management, [on-line]. [cit. 201505-13]. Available at: http://reputationhacks.com/guide-to-reputation-management-3-8-core-principles/.

Marsden, H. (2013), Guard Your Reputation On-line, Birmingham: Smartebookshop, ISBN: 123-0000-194-89-3.

Michalski, G., (2014), Value maximizing corporate current assets and cash management in relation to risk sensitivity: Polish firms case, Economic Computation and Economic Cybernetics Studies and Research, 48 (1), pp. 259-276

Pollák, F. (2013), e-Business and its application in the conditions of Slovak market, Prešov: Bookman, ISBN 978-80-89568-60-4.

Pollák, F., Dorčák, P. and Szabo, S., (2014), Analysis of the possibilities of improving an online reputation of public institutions, IDIMT 2014 - Networking societies - cooperation and conflict : 22nd interdisciplinary information management talks, Linz: Johannes Kepler Universität, pp 275-282, ISBN 978-3-99033-340-2

Rajzák, P. et al. (2010), Systém pre hodnotenie on-line reputácie bánk. Proceedings: Faculty of Electrical Engineering and Informatics of the Technical University of Košice, pp. 652-657, ISBN: 978-80-553-0460-1.

Sabater, J.; Sierra, C. (2003). Review on Computational Trust and Reputation Models. [on-line]. [cit. 2015-05-09]. Available at: http://www.iiia.csic.es/ sierra/articles/2005/SabaterSierra.pdf.

Siano, A. et al. (2011), Exploring the Role of On-line Consumer Empowerment in Reputation Building: Research Questions and Hypotheses. [on-line]. [cit. 2015-05-09]. Available at: http://www.academia.edu/1096337/Exploring_the_role_of_on-line_ consumer_empowerment_in_reputation_building_Research_questions_and_hypotheses.

Smaiziene, I.; Jucevicius, R. (2009), Corporate Reputation: Multidisciplinary Richness and Search for a Relevant Definition, In: Inzinerine Ekonomika-Engineering Economics. pp. 91-101. ISSN: 1392-2785.

Szczygiel, N., Rutkowska-Podolowska, M., Michalski G. (2015). Information and Communication Technologies in Healthcare: Still Innovation or Reality? Innovative and Entrepreneurial Value - creating Approach in Healthcare Management, in: 5th Central European Conference in Regional Science Conference Proceedings / Nijkamp Pater (ed.), Technical University of Košice, ISBN 978-80-553-2015-1, pp. 1020-1029. 
Šoltés, Vincent \& Gavurová, Beáta. 2013. Application of the cross impact matrix method in problematic phases of the Balanced Scorecard system in private and public sector. In: Journal of Applied Economic Sciences. Vol. 8, no. 1 (2013), p. 99-119. ISSN $1843-6110$

Šoltés, Vincent \& Gavurová, Beáta. 2015. Modification of Performance Measurement System in the intentions of Globalization Trends. In: Polish Journal of Management Studies. Vol. 11, no. 2 (2015), p. 160-170. ISSN 2081-7452

Tavakolifard, Mozghan \& Almeroth, C. Kevin. 2012. A Taxonomy to Express Open Challenges in Trust and Reputation Systems. In: Journal of Communications. Vol. 7, no. 7 (2012), p. 538-551. ISSN 1796-2021

Uddin, M., Zulkernine, M. and Ahamed, Sheikh I. 2008. CAT: A Context-Aware Trust Model for Open and Dynamic Systems. Proc. of the 23rd Annual ACM Symposium on Applied Computing (ACM SAC'08), Ceará, Brazil, March 2008, ACM Press.

Walsh, G.; Beatty, S. (2007), Customer-based Corporate Reputation of a Service Firm: Scale Development and Validation. In: Journal of the Academy of Marketing Science, Volume 35 Number 1, pp. 127-143. ISSN: 0092-0703.

Appendix A. Financial Performance Ratios

\begin{tabular}{|c|c|c|}
\hline Measurement Area & Ratio & Formula \\
\hline \multirow{2}{*}{ RETURN ON INVESTMENT } & Return on Assets Employed & $\frac{\text { Net Income }}{\text { Total Assets }}$ \\
\hline & Return on Equity \% & $\frac{\text { Not Income }}{\text { Total Equity }}$ \\
\hline \multirow{2}{*}{ LIQUIDITY } & Current Ratio & $\frac{\text { Current Assets }_{t}}{\text { Current Liabilities }_{t}}$ \\
\hline & Quick Ratio & $\frac{\text { Cash }_{t}+\text { Market securities }_{t}+\text { Accounts receivable }_{t}}{\text { Current Liabilities }}$ \\
\hline \multirow{2}{*}{ CAPITAL STRUCTURE \& SOLVENCY } & Debt To Equity Ratio & $\frac{\text { Debt }_{t}}{\text { Equity }}$ \\
\hline & Funded Capital Ratio & $\frac{\left(\text { Shareholders' } \text { Equit }_{t}+\text { Long-term Debts }_{t}\right)}{\text { Fixed Assets }}$ \\
\hline
\end{tabular}

Source: Bragg S.M. (2007)

Appendix B. On-line Reputation Score

\begin{tabular}{|c|c|c|c|c|c|c|c|c|c|c|c|}
\hline Rank & Company name & 12 & 2 & 34 & 5 & 6 & 7 & 8 & 9 & 10 & Total \\
\hline 1 & SÜDZUCKER AKTIENGESELLSCHAFT MANNHEIM/OCHSENFURT & 10 & $9 \sqrt{1}$ & 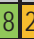 & 2 & 2 & 2 & 2 & 12 & 2 & 61 \\
\hline 2 & BARRY CALLEBAUT BELGIUM & 10 & 9 & 22 & 2 & 15 & 14 & 2 & 2 & 2 & 60 \\
\hline 3 & PERFETTI VAN MELLE S.P.A. & $1 0 \longdiv { 2 }$ & 2 & 8 & 16 & 2 & 2 & 13 & 2 & 2 & 59 \\
\hline 2 & BARILLA G. E R. FRATELLI - SOCIETA' PER AZIONI & 102 & 2 & 2 & 2 & 15 & 2 & 3 & 12 & 2 & 57 \\
\hline 5 & NUTRECO N.V. & 102 & 2 & 2 & 16 & 15 & 2 & 2 & 2 & 2 & 55 \\
\hline 6 & NESTLE FRANCE & 10 & 9 & 8 & 2 & 5 & 2 & 3 & 2 & 11 & 54 \\
\hline 6 & PURATOS & 105 & 9 & 8 & 6 & 5 & 4 & 2 & 2 & 1 & 54 \\
\hline 6 & CEDROB S.A. & $10 \sqrt{2}$ & 2 & 8 & $\sqrt{16}$ & 2 & 2 & 3 & 2 & 2 & 54 \\
\hline 9 & GROUPE BIGARD & 10 s & 9 & 8 & 2 & 2 & 14 & 2 & 2 & 2 & 53 \\
\hline 9 & LINDT \& SPRUNGLI S.P.A. & $10[2$ & 2 & 8 & 6 & 2 & 2 & 2 & 12 & 2 & 53 \\
\hline 9 & NORDZUCKER AG & 102 & 2 & 8 & 2 & 5 & 4 & 2 & 2 & 11 & 53 \\
\hline 12 & ARLA FOODS AB & $10 \sqrt{2}$ & 2 & 8 & 2 & 5 & 2 & 2 & 2 & 11 & 51 \\
\hline 13 & CAMPOFRIO FOOD GROUP & 10 & 9 & 8 & 6 & 2 & 2 & 2 & 2 & 2 & 50 \\
\hline 13 & ZVIJEZDA D.D. & 105 & 9 & 8 & 6 & 2 & 2 & 2 & 2 & 2 & 50 \\
\hline 15 & GLANBIA PUBLIC LIMITED COMPANY & 102 & 2 & 8 & 6 & 2 & 2 & 13 & 2 & 1 & 48 \\
\hline 15 & NESTLE ESPAÑA SA & 10 & 9 & 8 & 6 & 2 & 4 & 3 & 2 & 2 & 48 \\
\hline 17 & RAISIO OYJ & 102 & 2 & 2 & 16 & 2 & 2 & 2 & 2 & 2 & 47 \\
\hline 17 & AB ŻEMAITIJOS PIENAS & 10 & 9 & 8 & 2 & 2 & 2 & 3 & 2 & 2 & 47 \\
\hline 19 & PENAM. A.S. & 10 & 9 & 8 & 2 & 2 & 2 & 2 & 2 & 2 & 46 \\
\hline 20 & NWF GROUP PLC & 102 & 2 & 8 & 2 & 2 & 2 & 13 & 2 & 2 & 45 \\
\hline 21 & FROMAGERIES BEL & 102 & & 8 & 6 & 5 & 4 & 3 & 2 & 2 & 44 \\
\hline 21 & EBRO FOODS. SA & 10 & & 8 & 6 & 2 & 2 & 2 & 2 & 1 & 44 \\
\hline 21 & DEVRO PLC & 102 & & 2 & 2 & 5 & 15 & 2 & 2 & 2 & 44 \\
\hline
\end{tabular}




\begin{tabular}{|c|c|c|c|c|c|c|c|c|c|c|}
\hline 24 & MONDELEZ POLSKA S.A. & $1 0 \longdiv { 9 }$ & 27 & 72 & 5 & 2 & $\overline{2}$ & & & 43 \\
\hline 24 & LEDO D.D. & $1 0 \longdiv { 2 }$ & 87 & 76 & 2 & $\overline{2}$ & 2 & 2 & & 43 \\
\hline 26 & MANTUA SURGELATI - S.P.A. & $1 0 \longdiv { 9 }$ & 82 & $2 \mid$ & 2 & 2 & 2 & 2 & & 41 \\
\hline 26 & INALCA SOCIETA' PER AZIONI & $1 0 \longdiv { 2 }$ & 22 & 22 & 5 & 2 & 2 & 12 & & 41 \\
\hline 28 & SAINT LOUIS SUCRE SA & $1 0 \longdiv { 9 }$ & 22 & 22 & 5 & 4 & 2 & 2 & & 40 \\
\hline 28 & HERTA & $10 \mid 9$ & 27 & $7|2|$ & 2 & 2 & 2 & 2 & & 40 \\
\hline 28 & PASTIFICIO RANA S.P.A. & $1 0 \longdiv { 2 }$ & 87 & $7 \mid 2$ & 2 & 2 & 3 & 2 & & 40 \\
\hline 28 & NÖM AG & 109 & 27 & 72 & 2 & 2 & 2 & 2 & & 40 \\
\hline 28 & VODŇANSKÁ DRŬBEŽ. A.S. & $1 0 \longdiv { 9 }$ & 22 & 27 & 2 & 2 & 2 & 2 & & 40 \\
\hline 28 & GRUPO KALISE MENORQUINA SA & $1 0 \longdiv { 2 }$ & 27 & 76 & 5 & 2 & 2 & 2 & & 40 \\
\hline 34 & KOHBERG BAKERY GROUP A/S & $1 0 \longdiv { 2 }$ & 27 & 76 & 2 & 4 & 2 & 2 & & 39 \\
\hline 35 & ВИММ-БИЛЛЬ-ДАНН & $10 / 9$ & 22 & 22 & 5 & 2 & 2 & 2 & & 38 \\
\hline 35 & EUROPEAN FOOD SA & $1 0 \longdiv { 2 }$ & 27 & $7 \sqrt{2}$ & 5 & $\overline{4}$ & 2 & 2 & & 38 \\
\hline 37 & WAWEL S.A. & $1 0 \longdiv { 2 }$ & 22 & 26 & 5 & 4 & 2 & 2 & & 37 \\
\hline 37 & WYNNSTAY GROUP P.L.C. & $10 \mid 9$ & 22 & \begin{tabular}{|l|l|}
2 & 2
\end{tabular} & 2 & 4 & 2 & 2 & & 37 \\
\hline 37 & PRUTUL SA & $1 0 \longdiv { 9 }$ & 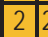 & 2 & 2 & $\overline{4}$ & 2 & 2 & & 37 \\
\hline 40 & MARINE HARVEST KRITSEN & $1 0 \longdiv { 9 }$ & 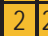 & \begin{tabular}{|l|l|}
2 & 2
\end{tabular} & 2 & 2 & 3 & 2 & & 36 \\
\hline 41 & LA DORIA - S.P.A. & $1 0 \longdiv { 2 }$ & 82 & $\begin{array}{l}22 \\
2\end{array}$ & 2 & 2 & 3 & 2 & & 35 \\
\hline 42 & SOCOPA VIANDES & $1 0 \longdiv { 2 }$ & 22 & \begin{tabular}{|c|}
26 \\
\end{tabular} & 2 & 4 & 2 & 2 & & 34 \\
\hline 42 & GREENYARD FOODS & $1 0 \longdiv { 2 }$ & 82 & 2 & 2 & 2 & 2 & 2 & & 34 \\
\hline 42 & VINDIJA D.D. VARAŽDIN & $10 \mid 2$ & 82 & 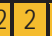 & 2 & 2 & 2 & 2 & & 34 \\
\hline 42 & INDYKPOL S.A. & $1 0 \longdiv { 2 }$ & 82 & 22 & 2 & 2 & 2 & 2 & & 34 \\
\hline 42 & LESIEUR & \begin{tabular}{|l|l|}
2 & 2 \\
\end{tabular} & 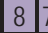 & 72 & 2 & 4 & 3 & 2 & & 34 \\
\hline 42 & KOFFIE F. ROMBOUTS - CAFES F. ROMBOUTS & $10 \mid 2$ & 82 & 22 & 2 & 2 & 2 & 2 & & 34 \\
\hline 48 & DAIRY CREST GROUP PLC & $1 0 \longdiv { 2 }$ & 22 & \begin{tabular}{l|l}
2 & 2 \\
\end{tabular} & 5 & 4 & 2 & 2 & & 33 \\
\hline 48 & HKSCAN OYJ & $2 \sqrt{9}$ & 82 & 22 & 2 & 2 & 2 & 2 & & 33 \\
\hline 48 & BROCELIANDE - ALH & 102 & 27 & 72 & 2 & 2 & 2 & 2 & & 33 \\
\hline 48 & MADETA A. S. & $1 0 \longdiv { 2 }$ & 22 & 22 & 5 & 4 & 2 & 2 & & 33 \\
\hline 52 & LA LINEA VERDE SOCIETA' AGRICOLA S.P.A. & $1 0 \longdiv { 2 }$ & 22 & 2 & 5 & 2 & 2 & 2 & & 31 \\
\hline 53 & CARR'S MILLING INDUSTRIES & 22 & 82 & 22 & 2 & $\overline{4}$ & 3 & 2 & & 29 \\
\hline 53 & FINSBURY FOOD GROUP PLC & $1 0 \longdiv { 2 }$ & 22 & 2 & 2 & 2 & 3 & 2 & & 29 \\
\hline 55 & LJUBLJANSKE MLEKARNE. MLEKARSKA INDUSTRIJA. D.D. & $1 0 \longdiv { 2 }$ & 22 & \begin{tabular}{|l|l|l}
2 &
\end{tabular} & 2 & 2 & 2 & 2 & & 28 \\
\hline 55 & MEBГА^ A.E. & $1 0 \longdiv { 2 }$ & 27 & 76 & 5 & 4 & 2 & -12 & & 28 \\
\hline 55 & MORAVSKOSLEZSKÉ CUKROVARY. A.S. & $1 0 \longdiv { 2 }$ & 22 & 22 & 2 & 2 & 2 & 2 & & 28 \\
\hline 58 & SANCHEZ CANO. SA & 22 & 27 & $7 \sqrt{2}$ & 2 & 4 & 2 & 2 & & 27 \\
\hline 59 & AUBRET & 22 & 22 & 22 & 2 & 2 & 2 & 2 & & 20 \\
\hline 60 & PARMALAT S.P.A. & $10 \mid 2$ & 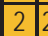 & 22 & 5 & & & & & 18 \\
\hline
\end{tabular}

Appendix C. The computation of six performance ratios

\begin{tabular}{|c|l|c|c|c|c|c|c|c|}
\cline { 4 - 8 } \multicolumn{2}{c|}{} & \multicolumn{4}{c|}{ Key Performance Indicators } \\
\hline Rank & Food companies & Country & ROA & ROE & Current & Quick & D/E & Fund Cap \\
\hline 1 & SÜDZUCKER & GERMANY & 0.0556 & 0.0730 & 1.8328 & 0.8339 & 1.1772 & 1.1841 \\
\hline 2 & BARRY CALLEBAUT BELGIUM & BELGIUM & 0.0298 & 0.0521 & 0.7249 & 0.4382 & 6.5515 & 0.7341 \\
\hline 3 & PERFETTI VAN MELLE S.P.A. & ITALY & 0.1518 & 0.1812 & 1.8138 & 1.2718 & 1.1464 & 1.6282 \\
\hline 2 & BARILLA G. E R. FRATELLI - S.P.A. & ITALY & 0.0876 & 0.1705 & 1.0036 & 0.8462 & 1.1525 & 0.8772 \\
\hline 5 & NUTRECO N.V. & NETHERL & 0.0741 & 0.2121 & 1.3372 & 1.0116 & 1.8347 & 1.3080 \\
\hline 6 & NESTLE FRANCE & FRANCE & 0.0835 & 0.1711 & 1.0505 & 0.8206 & 1.4553 & 0.8681 \\
\hline 6 & PURATOS & BELGIUM & 0.0239 & 0.1365 & 0.4367 & 0.3261 & 2.7707 & 0.6432 \\
\hline 6 & CEDROB S.A. & POLAND & 0.0820 & 0.1895 & 0.9440 & 0.6927 & 2.0973 & 0.9165 \\
\hline 9 & GROUPE BIGARD & FRANCE & 0.0378 & 0.0843 & 1.1800 & 0.8643 & 0.9759 & 1.0238 \\
\hline 9 & LINDT \& SPRUNGLI S.P.A. & ITALY & 0.0455 & 0.0307 & 1.5894 & 1.2256 & 1.6429 & 1.4214 \\
\hline 9 & NORDZUCKER AG & GERMANY & 0.0955 & 0.1355 & 1.6580 & 0.5897 & 1.5722 & 1.1284 \\
\hline 12 & ARLA FOODS AB & SWEDEN & 0.0254 & $0.1175)$ & 1.0627 & 0.6528 & 20.5364 & 0.6931 \\
\hline
\end{tabular}




\begin{tabular}{|c|c|c|c|c|c|c|c|c|}
\hline 13 & CAMPOFRIO FOOD GROUP & SPAIN & 0.0420 & 0.0399 & 1.2553 & 0.7365 & 2.3317 & 0.9838 \\
\hline 13 & ZVIJEZDA D.D. & CROATIA & 0.0291 & 0.0253 & 2.0061 & 1.4065 & 0.4161 & 1.2854 \\
\hline 15 & GLANBIA PUBLIC LIMITED COMPANY & IRELAND & 0.0868 & 0.3189 & 1.6548 & 1.0541 & 3.8852 & 1.0489 \\
\hline 15 & NESTLE ESPAÑA SA & SPAIN & 0.0695 & 0.2298 & 0.7196 & 0.5492 & 5.0633 & 0.7153 \\
\hline 17 & RAISIO OYJ & FINLAND & 0.0216 & 0.0861 & 3.1882 & 2.3182 & 0.4174 & 2.0329 \\
\hline 17 & AB ŽEMAITIJOS PIENAS & \begin{tabular}{|l|} 
LITHUANIA \\
\end{tabular} & 0.0954 & 0.1344 & 2.3924 & 1.1332 & 0.8287 & 1.8672 \\
\hline 19 & PENAM. A.S. & CZECH REP & 0.0659 & 0.0969 & 1.1105 & 0.9920 & 0.8254 & 0.9462 \\
\hline 20 & NWF GROUP PLC & UK & 0.0759 & 0.1252 & 1.1912 & 1.0815 & 2.7904 & 0.9368 \\
\hline 21 & FROMAGERIES BEL & FRANCE & 0.0841 & 0.0976 & 1.5689 & 1.1724 & 1.0818 & 1.0786 \\
\hline 21 & EBRO FOODS. SA & SPAIN & 0.0788 & 0.1237 & 1.4431 & 0.9089 & 1.1947 & 0.9125 \\
\hline 21 & DEVRO PLC & UK & 0.1412 & 0.2014 & 1.9493 & 1.1758 & 1.0300 & 0.9243 \\
\hline 24 & MONDELEZ POLSKA S.A. & POLAND & 0.2501 & 0.3407 & 2.1241 & 1.8363 & 0.6465 & 2.2630 \\
\hline 24 & LEDO D.D. & CROATIA & 0.0900 & 0.1223 & 2.5434 & 1.9153 & 0.6868 & 1.5966 \\
\hline 26 & MANTUA SURGELATI - S.P.A. & ITALY & 0.0537 & 0.0724 & 1.0979 & 0.7201 & 1.9117 & 0.9818 \\
\hline 26 & INALCA SOCIETA' PER AZIONI & ITALY & 0.0526 & 0.0661 & 1.1118 & 0.5842 & 1.9959 & 0.9534 \\
\hline 28 & SAINT LOUIS SUCRE SA & FRANCE & 0.0309 & 0.1121 & 1.1354 & 0.6834 & 1.4524 & 0.9919 \\
\hline 28 & HERTA & FRANCE & 0.1706 & 0.3372 & 1.1368 & 1.0110 & 2.7446 & 1.1809 \\
\hline 28 & PASTIFICIO RANA S.P.A. & ITALY & 0.0479 & 0.0725 & 0.9691 & 0.8706 & 4.2485 & 0.8362 \\
\hline 28 & NÖM AG & AUSTRIA & 0.0679 & 0.1295 & 0.8858 & 0.7395 & 2.2929 & 0.5775 \\
\hline 28 & VODÑANSKÁ DRÜBEŽ. A.S. & CZECH REP & $(0.0247)$ & 0.3439 & 0.7678 & 0.6074 & -1.2365 & -32.8398 \\
\hline 28 & GRUPO KALISE MENORQUINA SA & SPAIN & 0.0116 & $0.0147)$ & 1.0709 & 0.7018 & 1.0201 & 0.9302 \\
\hline 34 & KOHBERG BAKERY GROUP A/S & DENMARK & 0.0483 & 0.0899 & 1.7917 & 1.6521 & 2.1404 & 1.3606 \\
\hline 35 & ВИММ-БИЛЛЬ-ДАНН & RUSS.FED. & 0.1056 & 0.1069 & 1.1032 & 0.7536 & 1.0111 & 0.9969 \\
\hline 35 & EUROPEAN FOOD SA & ROMANIA & 0.0368 & 2.3380 & 0.6479 & 0.2873 & -15.2967 & 0.5520 \\
\hline 37 & WAWEL S.A. & POLAND & 0.1738 & 0.2179 & 2.0523 & 1.6500 & 0.4553 & 1.3816 \\
\hline 37 & WYNNSTAY GROUP P.L.C. & UK & 0.0612 & 0.0907 & 1.4804 & 1.0405 & 0.9759 & 1.6299 \\
\hline 37 & PRUTUL SA & ROMANIA & 0.0588 & 0.0254 & 0.8605 & 0.3855 & 3.6735 & 0.6254 \\
\hline 40 & MARINE HARVEST KRITSEN & FRANCE & 0.0599 & 0.0917 & 1.4122 & 1.1303 & 1.9019 & 1.8661 \\
\hline 41 & LA DORIA - S.P.A. & ITALY & 0.0566 & 0.0872 & 1.4853 & 0.6453 & 2.4326 & 1.6727 \\
\hline 42 & SOCOPA VIANDES & FRANCE & 0.0265 & 0.0494 & 1.2313 & 0.8099 & 2.5839 & 1.4194 \\
\hline 42 & GREENYARD FOODS & BELGIUM & 0.0224 & $0.0169)$ & 1.1359 & 0.5214 & 2.6658 & 0.9282 \\
\hline 42 & VINDIJA D.D. VARAŽDIN & CROATIA & 0.0231 & 0.0588 & 0.9771 & 0.8623 & 2.0526 & 0.9689 \\
\hline 42 & INDYKPOL S.A. & POLAND & 0.0387 & 0.0382 & 1.2611 & 0.8915 & 1.6015 & 0.9826 \\
\hline 42 & LESIEUR & FRANCE & 0.0698 & 0.0634 & 1.4859 & 1.0168 & 0.7712 & 1.1594 \\
\hline 42 & KOFFIE F. ROMBOUTS - CAFES F. ROMBOUTS & BELGIUM & 0.0600 & 0.1024 & 1.2420 & 0.8785 & 2.3761 & 1.2193 \\
\hline 48 & DAIRY CREST GROUP PLC & UK & 0.0613 & 0.1427 & 1.4553 & 0.7723 & 2.3233 & 1.0317 \\
\hline 48 & HKSCAN OYJ & FINLAND & 0.0467 & 0.0673 & 1.2107 & 0.8275 & 1.7705 & 1.0230 \\
\hline 48 & BROCELIANDE - ALH & FRANCE & 0.0024 & 0.0294 & 0.7760 & 0.5401 & -4.7224 & 0.5210 \\
\hline 48 & MADETA A. S. & CZECH REP & 0.0671 & 0.1167 & 0.9034 & 0.6092 & 1.8934 & 0.7151 \\
\hline 52 & LA LINEA VERDE S.P.A. & ITALY & 0.0208 & 0.0044 & 0.7760 & 0.7197 & 8.0569 & 0.5947 \\
\hline 53 & CARR'S MILLING INDUSTRIES & UK & 0.0729 & 0.2123 & 1.4072 & 1.0200 & 2.2148 & 1.1508 \\
\hline 53 & FINSBURY FOOD GROUP PLC & UK & 0.0644 & 0.1240 & 0.7575 & 0.6539 & 1.8370 & 0.8176 \\
\hline 55 & LJUBLJANSKE MLEKARNE. D.D. & SLOVENIA & $(0.0074)$ & $\overline{0.0231)}$ & 1.1606 & 0.8852 & 1.0841 & 1.0053 \\
\hline 55 & МЕВГА^ А.Е. & GREECE & 0.0121 & $0.2451)$ & 0.9949 & 0.7549 & 4.9506 & 0.9582 \\
\hline 55 & MORAVSKOSLEZSKÉ CUKROVARY. A.S. & CZECH REP & 0.2147 & 0.1763 & 3.0040 & 1.3687 & 0.3838 & 3.1811 \\
\hline 58 & SANCHEZ CANO. SA & SPAIN & 0.1706 & 0.1968 & 1.7925 & 0.9597 & 0.8050 & 1.4869 \\
\hline 59 & AUBRET & FRANCE & 0.0385 & 0.1224 & 1.2801 & 0.8005 & 3.0614 & 1.4001 \\
\hline 60 & PARMALAT S.P.A. & ITALY & 0.0858 & 0.1079 & 2.8518 & 2.3800 & 0.5857 & 1.5644 \\
\hline
\end{tabular}


Appendix D. Dispersion Graphs
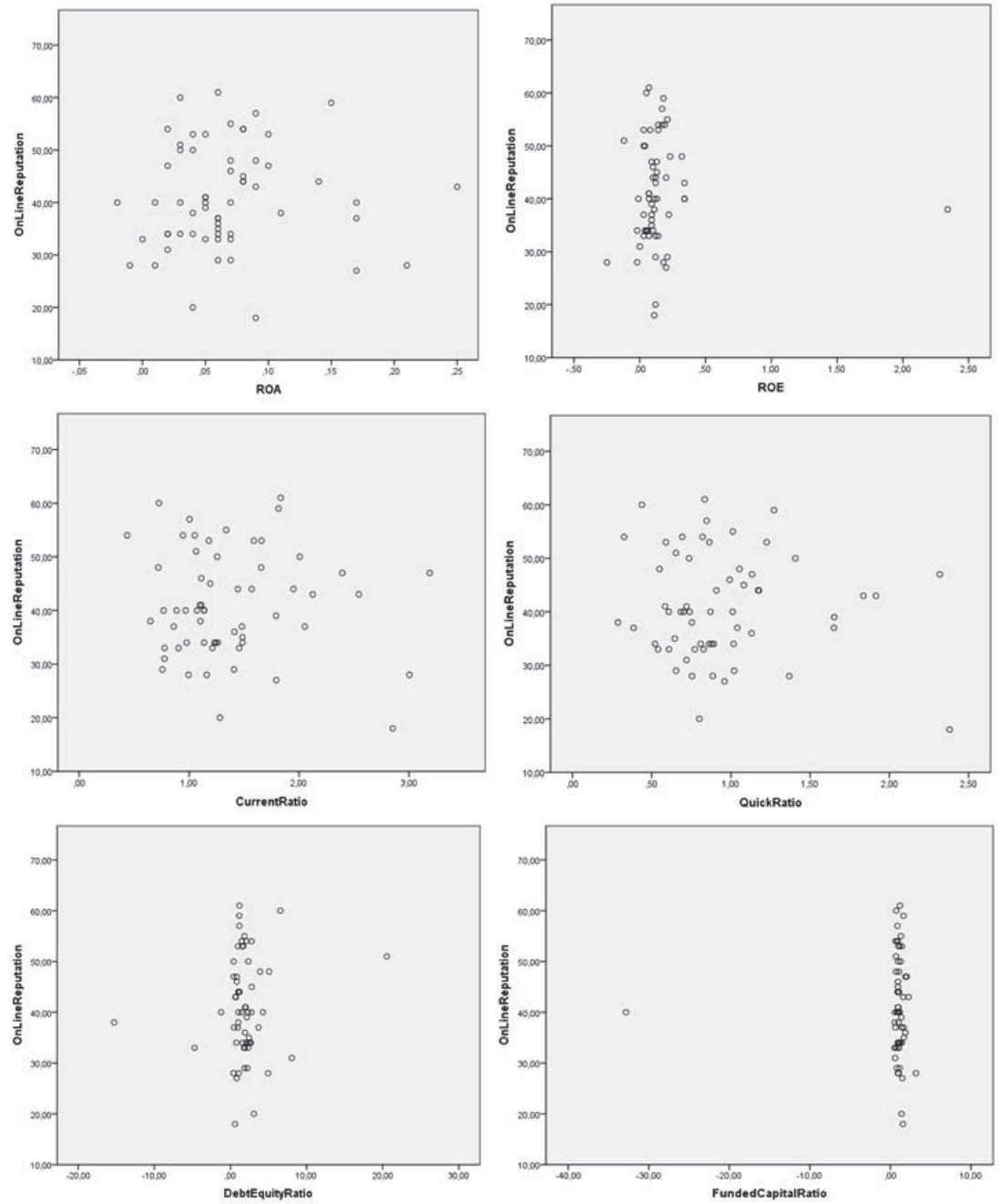